\title{
PENGGUNAAN MODEL PEMBELAJARAN INTERAKTIF UNTUK MENINGKATKAN PRESTASI BELAJAR IPS DALAM MATERI KENAMPAKAN ALAM DAN SOSIAL NEGARA-NEGARA TETANGGA PADA SISWA KELAS VI SD NEGERI 09 KABAWETAN
}

\author{
Sukamto \\ SD Negeri 09 Kabawetan, Kepahiang
}

\begin{abstract}
Abstrak
Penelitian ini bertujuan untuk meningkatkan prestasi belajar IPS siswa SD melalui penggunaan model pembelajaran interaktif. Penelitian ini merupakan Penelitian Tindakan Kelas (PTK) yang terdiri dari 2 siklus. . Subjek penelitiannya adalah siswa kelas VI SDN 09 Kabawetan. Hasil yang diperoleh dari penelitian yaitu ada peningkatan prestasi belajar siswa secara signifikan dari pra siklus, siklus 1 ke siklus 2 dengan rata-rata nilai yang diperoleh : pada pra siklus dari 16 siswa prestasi belajar siswa mengalami peningkatan belajar dari pra siklus, siklus $1 \mathrm{ke}$ siklus 2 dengan rata-rata nilai yang diperoleh : pada pra siklus dari 16 siswa, dengan nilai rata-rata 66,25 pada pra siklus yang tuntas belajar hanya 56,25\% atau 9 anak, sedangkan siswa yang tidak berhasil 44,75 atau 7 anak. Pada siklus 1 nilai rata-rata 68,75 meningkat yaitu siswa yang tuntas dalam belajar $62,50 \%$ atau 10 anak sedangkan yang belum tuntas 33,50\% atau 6 anak. Pada siklus 2 ada kenaikan yang cukup signifikan yaitu rata-rata nilai menjadi 75 sesuai dengan yang diharapkan, dengan hasil ketuntasan belajar mencapai 87,50\% atau 14 anak sedangkan yang belum tuntas $12,50 \%$ atau 2 anak. Berdasarkan hasil penelitian, penerapan pembelajaran menggunakan model pembelajaran interaktif dapat meningkatkan prestasi belajar dan pemahaman konsep tentang materi Kenampkan alam dan sosial negara-negara tetangga pada kelas VI SD Negeri 09 Kabawetan Kecamatan Kabawetan Kabupaten Kepahiang, Provinsi Bengkulu.
\end{abstract}

Kata Kunci: Interaktif, Kenampakan alam dan prestasi belajar

\section{PENDAHULUAN}

Dalam proses mengajar guru menjadi pemeran utama dalam menciptakan situasi interaktif yang edukatif, yakni interaksi antara guru dengan siswa, siswa dengan siswa dan dengan sumber pembelajaran dalam menunjang tercapainya tujuan belajar. Untuk terwujudnya proses belajar mengajar seperti itu sudah tentu menuntut upaya guru untuk mengaktualisasikan kompetensinya secara profesional, utamanya aspek metodologis.

IPS sebagai salah satu bidang studi yang memiliki tujuan membekali siswa untuk mengembangkan penalarannya disamping aspek nilai dan moral, banyak memuat materi sosial bersifat hapalan sehingga pengetahuan dan informasi yang diterima siswa sebatas produk hapalan. Sifat pelajaran IPS tersebut membawa konsekuensi terhadap proses belajar mengajar yang didominasi oleh pendekatan 
ekspositoris, terutama guru menggunakan metode ceramah sedangkan siswa kurang terlibat atau cenderung pasif. Dalam metode ceramah terjadi dialog imperaktif. Padahal, dalam proses belajar mengajar keterlibatan siswa harus secara totalitas, artinya melibatkan pikiran, penglihatan, pendengaran, dan psikomotorik (keterampilan, salah satunya sambil menulis). Jadi, dalam proses belajar mengajar, seorang guru harus mengajak siswa untuk mendengarkan, menyajikan media yang dapat

Berdasarkan hasil observasi dan informasi yang diberikan oleh guru di SD Negeri 09 Kabawetan. Khususnya kelas VI terdapat permasalahan yang dihadapi oleh siswa yaitu kurangnya motivasi dari diri siswa dalam mengikuti proses belajar mengajar mata pelajaran IPS, pernyataan tersebut didasarkan pula pada hasil nilai ulangan harian siswa pada mata pelajaran IPS yang cukup rendah daya serap siswa secara klasikal masih dibawah standar minimum yaitu $75 \%$ secara rinci dari 16 siswa kelas VI di SD Negeri 09 Kabawetan yang mendapat nilai 90 adalah 2 (satu) siswa (12,5\%) 80 adalah 3 siswa (18,75\%), yang mendapat nilai 70 sebanyak 4 siswa ( $25 \%$ ), yang mendapat nilai 60 sebanyak 2 siswa $(12,5 \%)$, yang mendapat nilai 50 sebanyak 5 siswa ( $25 \%$ ) yang mendapat nilai 40 sebanyak 1 siswa ( 6,25\%). Fakta ini menunjukkan bahwa siswa SD Negeri 09 Kabawetan belum mencapai ketuntasan belajar pada mata pelajaran IPS.

Setelah kegiatan pembelajaran selesai peneliti mengadakan diskusi dengan teman sejawat, hasil diskusi dengan teman sejawat ditemukan beberapa masalah yang terjadi dalam proses belajar mengajar yaitu :
1. Kurangnya interaksi antara guru dan siswa

2. Penguasaan guru tentang metode pengajaran masih belum maksimal.

3. Siswa cenderung pasif dan kurangnya motivasi siswa.

4. Metode yang digunakan dalam mengajar belum bervariasi/ monoton.

5. Siswa cenderung hanya menghafal bukan memahami materi pelajaran.

\section{METODE}

Penelitian ini dilaksanakan di SD
Negeri 09 Kabawetan Kecamatan
Kabawetan Kabupaten Kepahiang. Penelitian
ini dilaksanakan selama 2 siklus, yaitu pada
tanggal 15 Oktober 2014 ( siklus 1) dan 22
Oktober 2014 ( 2 )
Oktober 2014 ( siklus 2 ). Mata pelajaran yang diteliti adalah Ilmu Pengetahuan Soaial dengan materi Kenampakan alam dan sosial negara-negara tetangga bagi kelas VI semester I SD Negeri 09 Kabawetan tahun pelajaran 2014/2015.

Analisis data hasil observasi selama proses pembelajaran berlansung berupa deskritif kualitatif. Dalam pelaksanaan observasi peneliti dibantu oleh observer untuk mengisi daftar ceklist lembar observasi yang telah disiapkan. Adapun aspek yang diobservasi melupiti keaktifan siswa dalam memperhatikan dan mendengarkan penjelasan guru, bertanya, menjawab dan mengemukakan pendapat, serta kegiatan dalam pembelajaran dengan menggunakan metode demontrasi.

Ketuntasan hasil belajar siswa dapat dilihat dari perolehan skor siswa setelah mengikuti pembelajaran IPS dengan menggunakan metode demontrasi . untuk menghitung jumlah skor digunakan pedoman sebagai berikut : 


$$
\mathrm{P}=\frac{n}{N} \times 100 \%
$$

Keterangan :

$\mathrm{P}=$ Prosentase ketuntasan belajar

$\mathrm{n}=$ Jumlah siswa yang tuntas

belajarnya

$\mathrm{N}=$ Jumlah seluruh siswa

\section{Refleksi}

Kegiatan pada siklus I ini merupakan refleksi yang akan kami gunakan dalam melihat kekurangan dan kelebihan yang memungkin timbul pada perbaikan pembelajaran, sehingga dapat kami temukan beberapa kekuatan dan kelemahan pada diri peneliti. Antara lain :

\section{PEMBAHASAN}

\section{Siklus I}

\section{Rencana}

Rencana perbaikan peembelajaran yang peneliti susun antara lain meliputi: mengadakan tanya jawab dan diskusi tentang kenampakan alam, sosial budaya negaranegara tetangga. siswa berdiskusi dan melakukan tanya jawab tentang kenampakan alam dan sosial negara-negara tetangga.

\section{Pelaksanaan}

Adapun pelaksanaan dari rencana pembelajaran antara lain sebagai berikut :

Guru menjelaskan materi dengan melakukan tanya jawab dengan siswa

membimbing siswa dalam mengerjakan LKS membahas LKS untuk mengukur kemampuan siswa dalam menerima pelajaran dari guru

\section{Pengamatan / Pengumpulan Data/ Instrumen}

Beberapa aspek yang diamati antara lain :

1. Menjelaskan konsep kenampakan alam

2. Memimpin diskusi kelompok

3. Membimbing siswa diskusi

4. Menarik kesimpulan dari pelaksanaan diskusi

\section{a. Kekuatan}

Dengan mengadakan perbaikan pembelajaran ini peniliti lebih rinci dalam melihat permasalahan yang sering timbul pada pembelajaran pada umumnya, maka peniliti juga bisa segara membuat rencana perbaikan yang bisa meminimalkan masalah yang ada.

\section{b. Kelemahan}

Pada saat ini ternyata penelitian yang dilakukan oleh peniliti jarang tidak bisa diakui keabsahannya, karena penelitian ini dilakukan dalam skala yang sempit ( hanya pada kelompok-kelompok tertentu).

\section{Siklus 2}

\section{Rencana}

Pada pelaksanaan pembelajaran siklus 1, ternyata hasil evaluasi belajar siswa menunjukkan bahwa pemahaman tentang kenampakan alam dan sosial negara-negara tetangga masih kurang untuk itu peneliti membuat rencana perbaikan pembelajaran yang sesuai dengan tujuan perbaikan pembelajaran yang telah ditetapkan.

Berdasarkan faktor-faktor kurang berhasilnya pembelajaran IPS yang telah dilaksanakan maka peneliti merancang rencana secara umum dalam melaksanakan 
perbaikan pembelajaran materi diantaranya sebagai berikut:

1. Mengadakan dialog dengan siswa dan membahas tentang materi yang telah diajarkan namun belum banyak yang memahaminya

2. Memberikan tugas kelompok yang berupa lembar kerja keompok, sehingga peneliti dapat mengukur kemampuan siswa dalam memahami pembelajaran.

3. Menggunakan metode pembelajaran yang bervariasi yaitu metode ceramah, metode tanya jawab, presentasi dan pemberian tugas secara kelompok.

Adapun tahapan-tahapan perencanaan perbaikan pembelajaran sebagai berikut :

1. Membuat rencana perbaikan pembelajaran secara tertulis yang berisi langkah-langkah pelaksanaan pembelajaran yang sekiranya siswa dapat dengan mudah mengikuti pembelajaran.

2. Menyiapkan lembar observasi yang merupakan hasil kesepakatan antara peneliti dengan teman sejawat yang bertindak sebagai selaku pengamat.

3. Membuat lembar kerja kelompok untuk mengetahui tingkat keberhasilan pembelajaran siswa.

\section{Pelaksanaan}

Dalam pelaksanaan pembelajaran harus memperhatikan beberapa hal terutama tujuan yang hendak dicapai. Sedangkan langka-langkah perbaikan pembelajaran yang akan dilaksanakan yaitu :

a. Mengisi LKS yang sudah disediakan.

b. Mendeskripsikan kenampakan alam dengan kalimat runtut c. Mengadakan tanya jawab mengenai halhal yang berhubungan dengan materi.

d. Siswa mengerjakan soal postes.

e. Secara bersama-sama siswa membuat kesimpulan hasil belajar.

\section{Pengamatan/Pengumpulan Data}

Dalam melaksanakan perbaikan pembelajaran ini kami dibantu oleh rekan sejawat yang bertindak sebagai pengamat yaitu bapak Azis, S.Pd.SD. Dengan demikian akan diperoleh data-data yang memang, sangat kami butuhkan dalam mengadakan perbaikan pembelajaran ini. Agar pengamat ini dapat berjalan dengan baik maka kami memulai dari kesepakatan antara pengamat dengan peneliti, hal ini bertujuan agar pengamatan yang dilaksanakan lebih terarah pada masalah yang akan diamati.

Beberapa aspek yang diamati antara lain, sebagai berikut :

a. Menjelaskan konsep kenampakan alam

b. Memimpin diskusi kelompok

c. Membimbing siswa berdiskusi

d. Menarik kesimpulan

\section{Refleksi}

Kegiatan siklus 2 selanjutnya adalah refleksi yang berguna untuk menemukan beberapa hal yang telah dilakukan sehingga peneliti dapat mengetahui beberapa hal yang menjadi kekuatan dan kelemahan diri yaitu :

\section{a. Kekuatan}

Bebagai hal yang menjadi kekuatan atau manfaat antara lain peneliti dapat secara langsung memperbaiki pratik-praktik pembelajaran yang selama ini dilakukan agar menjadi lebih baik dan efektif karena dapat melihat/merasakan /menghayati dan bisa menawarkan cara baru untuk memperbaiki dan meningkatkan profesionalisme guru 
dalam kegiatan pembelajaran. Dengan cara melihat berbagai indikator keberhasilan proses dan hasil pembelajaran yang terjadi pada siswa.

\section{b. Kelemahan}

Validasi PTK ini masih sering dipertanyakan karena metodologi yang agak longgar yang bersifat informal meskipun dijaga keobjektifannya masih menimbulkan keraguan. Hasil penelitian yang dilakukan tidak dapat digeneralisasikan karena memang hasil tersebut hanya terkait dengan siswa didalam kelas yang telah disesuaikan dengan situasi dan kondisi yang ada.

1. Prosedur Pelaksanaan

Langkah yang ditempuh dalam perbaikan pembelajaran mata pelajaran IPS :

a. Sebagai kegiatan awal guru mengadakan tanya jawab dengan siswa.

b. Menyajikan materi melalui metode ceramah dan diskusi dengan siswa

c. Melakukan pengamatan di luar kelas.

d. Menganalisa LKS

e. Manarik kesimpulan

f. Memberi tugas dan pekerjaan rumah

Sesuai masalah yang dihadapi yaitu banyaknya siswa yang kurang memahami materi, yang menjadi perhatian khusus dalam perbaikan pembelajaran IPS kelas VI adalah mengupaayakan agar siswa dapat termotivasi minat untuk belajar sehingga dapat ditingkatkan hasil belajarnya.

\section{SIMPULAN}

Pada pra peembelajaran jumlah siswa yang tidak tintas dalam mengikuti pembelajaran sangat tinggi. Setelah dilaksankan perbaikan pembelajaran pada siklus 1 nampak sekali peningkatan hasil belajar siswa yaitu sebesar $62,50 \%$ atau 10 siswa sudah tuntas dan 6 siswa belum tuntas. Pada siklus 2 mengalami peningkatan secara signifikan sebesar $87,50 \%$.

Berdasarkan uraian pembahasan dan hasil penelitian diatas mulai siklus 1 sampai siklus 2 mengenai penggunaan model pembelajaran interaktif, dapat penulis simpulkan bahwa:

1. Dengan menggunakan pembelajaran interaktif, ternyata mampu meningkatkan prestasi belajar siswa kelas VI SD Negeri 09 Kabawetan pada materi kenampakan alam dan sosial negara-negara tetangga

2. Melalui pembelajaran interaktif, siswa dapat lebih aktif dalam kegiatan belajar, terutama pada mata pelajaran IPS.

\section{SARAN}

Berdasarkan kesimpulan diatas serta hasil perbaikan dan pembelajaran, agar kegiatan belajar mengajar Ilmu Pengetahuan Sosial yang membahas mengenai" Kenampakan Alam Dan Sosial NegeraNegara tetangga" anak lebih aktif, kreatif dan memberikan hasil yang optimal bagi siswa. Maka ada beberapa saran yang dapat disampaikan sebagai berikut :

1. Dalam kegiatan pembelajaran IPS sebaiknya guru menggunakan model pembelajaran interaktif, karena denga model pembelajaran tersebut dapat meningkatkan prestasi belajar siswa.

2. Guru hendaknya menerapkan pembelajaran interaktif, terutama pada mata pelajaran IPS, karena dapat mengaktifkan siswa dalam pembelajaran. 


\section{DAFTAR PUSTAKA}

Harlen1992. Model Pembelajaran Interaktif. London: Kogon Page

Nanik Budi.2008. Ilmu Pengetahuan Sosial Kelas VI. Jakarta: Intan Pariwara

Winaputra, S Udin.2005. Materi dan Pembelajaran. Jakarta : Universitas Terbuka

Suciati.2007. Belajar dan Pembelajaran 2. Jakarta: Universitas Terbuka

Winaputra ,S Udin.2005. Strategi Belajar Mengajar. Jakarta : Universitas

Sudjana.1990. Prestasi Belajar. Jakarta: Rineka Cipta Terbuka

Wardani I.G.A.K, dkk.2006. Penelitian

Sukardi.1983. Pedoman Penilaian. Jakarta : Rineka Cipta

Tindakan Kelas (PTK). Jakarta : Universitas Terbuka 